\title{
Politics And Gender Health Policy In Nigeria: A Study Of The Challenges Of Toxemias Of Pregnancy And The Peurperium Among Tiv Women Of Central Nigeria.
}

\author{
Tyodzua Atim (Ph.D) \\ Department of Political Science Benue State University, Makurdi
}

\begin{abstract}
One of the least researched and neglected area of research has been the political economy bases of health. The paper has acknowledged the per curial health problem and needs of women and attempts a study of the social, political, cultural and economic effects of Toxemias of pregnancy and the puerperium among Tiv women of Central Nigeria. The paper further identified the elements of the political base of health as being the use of political power to determine the ownership of the means of living and the sharing of society's wealth among individuals in Nigeria. The paper focuses on the Tiv rural community of Central Nigeria and has highlighted the Nigerian National Health Policy and the socio-cultural gender discriminations afflicting the country. The paper is of the opinion that political factors and discriminatory health policies have contributed to the high degree and spread of human suffering and sees political authority, a determinant of allocation of values as a major stumbling block to gender played, are playing and will continue to play in changing the social, economic and cultural determinant of the health and other aspects of life of the womenfolk.
\end{abstract}

\section{Introduction}

European social sciences became part of European medicine between 1850s and 1950s when the patient with their diseases became the focus of research. Before this development, attention was on studying the animal cell and bacteria and the invention of laboratory tools for the purposes of examining and identifying animal diseases. With the shift of attention to man, the patient was placed in the context of the community, social group, the environment and relationship between, the culture of a people and occurrences of certain diseases became the centre of attention. This paper among other issues focuses on the socio-economic factors responsible for a peculiar health problem among Tiv women of central Nigeria and to what extent the government has gone into fulfilling their aspirations. It was out of the study's quest to find solutions and answers to a fundamental health problem common to women and yet so widen, the desire to know the root causes of these that being unsatisfied with answers got from the numerous affected patients around hospitals and government health clinic, that the researcher decided to brings to light this women health problem Toxemias of Pregnancy that is common among Tiv women of Benue State. Due precisely to their low level of educational attainment, $99 \%$ of the women interviewed when asked of their most prevalent health problem simply answered "Stomach Ache" (Yav).

This paper further seeks an examination of Nigeria Health policy and its socio-economic and political implication among Tiv women of central Nigeria. The paper has noted that there exist fundamental health challenges that are peculiar to women, which require special medical attention and that government health policies are not designed in such a manner that the problems are adequately addressed. The paper has provided some conceptual clarifications. The problems associated with women during child birth. The lack of will by political holders at addressing the health problems of the people, a graphic presentation of health institutions in Tiv land viz-a-viz the socio-political, cultural and economic implications for womanhood presentation of health institutions in Tiv land viz-a-viz the socio-political, cultural and economic implications for womanhood viz-aviz the socio-political, cultural and economic implications for womanhood.

The level of poverty, hunger, squalor and degradation in Nigeria has reached such a magnitude that one is bound to wonder whether the basis for the survival of the African woman under the umbrella of Nigeria's capitalist incremenlist health policies, would ever save the African woman from the "complications of pregnancy and child birth. The culminating socio-economic factors responsible for these complications and the resultant effects which is usually death, is perhaps the primary concern of this research. The story becomes more glaring in a country like Nigeria where the absence of a cohesive ideological orientation prevents the government from taking action in solving women percurial health problems. The study adopted the interview and focused group discussion methodology in analyzing action and processing of data collated, used a theoretical framework of analysis, conceptual clarification, discussion and recommendations. 


\section{Methodology.}

In the words of Cohen and Manion ${ }^{2}$, methodology refers to the range of approaches used in research to gather data, which are to be used as a basis for Inferences and Interpretation. For this study, the researcher made use of several instruments of data collection, firstly, the study utilized the interview method, and the focused group Discussion as it's primary instruments of data source. The use of interview instrument and focused Group Discussion is an innovative method. It is imperative for this study because as a survey instrument, it involved a face to face communication interaction between the seeker and giver (provider) of information;and since the population of study are predominantly illiterate and residing in the rural communities, the researcher found its very convenient using these method because it elicits the local language 'Tiv'.

Specifically, the study, interviewed and had a focused discussion with amongst the principal administrative officers in the study area. ${ }^{3}$ These includes;

1. Dr. Shinyi G. Chief Gynecologist, General Hospital Makurdi.

2. Sister Amode E. (Mrs.) Nursing sister maternal and child care center Makurdi.

3. Chief statistics officer Benue State Health Services Management Board Makurdi.

On the other hand, the study also applied the documentary method of data collection. Although this is purely a secondary source of data collection, it afforded the researcher the opportunity to access statistical documented records on the issues under discussion. These include; data on the complications of pregnancy and the peurperium in the state and the nature of pregnancy related diseases common to Tiv women in Benue State. These records, provided hard facts for drawing conclusions and establishing trends on the topic under study.

\section{Population of Study and Sample Size.}

As earlier stated in the abstract, this study focuses predominantly on the Tiv women of Central Nigeria. The Tiv is a major ethnic group in Benue State of Central Nigeria; occupying about 14 local government out of the 23 local government that make up Benue State. The Tiv have their traditional head quarters in Gboko where the paramount ruler (Tor Tiv) resides. With its capital at Makurdi, Benue State occupies a large area of land totaling about $34,059 \mathrm{Sq} ; \mathrm{km}$, with a population of about 4.2 million people. Benue state is a rich agricultural region, with a vast majority of the population engaging in farming in the rural areas. The choice of Tiv women as the population of study, is based on the fact that majority of the Tiv women are illiterates who live and cultivate the land in their villages and rural settlements, as such are mostly affected by the toxemias of Although Benue State boasts of over 250 health related centers, such as hospitals, rural health centers, maternity clinics e.t.c. only about 136 of these facilities are located within the Tiv speaking areas, although. The study, has however shown that most of these health infrastructure are in shambles as such cannot take care of the health needs of the people particularly in the rural areas. Because of this, the study sampled three most outstanding health facilities in the state, which are; the Makurdi General Hospital; the Maternal and Child Care Center Makurdi and the Gbemacha Dispensary in Mbatiav clan of Gboko Local Government Area of the state. ${ }^{6}$

The study adopted the purposive or judgmental sampling as its methodology. This connotes the handpicking of desired sample elements to ensure that such elements are included. We cannot neglect the impact of classes in our analysis of pregnant women particularly, among the Tiv. The effects on Tiv women is more severe on the illiterate ones when compared to their literate counterparts. As such by adopting the purposive technique of sampling, conscious efforts were made by the study to sample mainly the rural women, whose lower social status bear heavier burden. This also informed the selection of health infrastructures sampled in the state. Majority of patients admitted to these hospitals are rural women who cannot afford expensive and specialized care in private hospitals within and outside the state.

In the same vein, the study made use of the tabular presentation as its main method. Tabular presentation connotes an orderly display of data in labeled rows and columns. The emphasis is to arrange data, in such a manner that the eye can easily recognize at a glance, the important results and if possible discover connection between intervening factors and variables. ${ }^{4}$

\section{Conceptual Clarification}

Toxemia of Pregnancy is a disorder characterized by high blood pressure, tissue swelling and protein in the urine of a pregnant woman. Severe toxemia of pregnancy can lead to eclampsia and coma and is considered rare condition of late pregnancy in which the mother develops seizures and can become unconscious, or comatose, and die. Enclampsia is almost always preceded by a condition called pre-enclampsia in which the woman has swelling, high blood pressure and protein in her urine. In about one pregnancy in 1000 preenclampsia, leads to enclampsia in late pregnancy during labour or delivery. It must be treated in the hospital to protect the lives of both the baby and mother. According to the Bailliere's Nurses Dictionary, Toxemias is the "poisoning of the blood by the absorption of toxins, characterized by the albuminuria, hypertension and edema, with the possibly of eclampsia developing if untreated." During the first stage of this complication, which is usually referred to as the pre-eclampsia, ${ }^{8}$ which occurs usually during three months of pregnancy, the affected 
patient develops high blood pressure. There is also a change in the kidney, which causes the patient to lose procaine in urine.

\section{Theoretical Framework.}

The feminism theory has amongst other things, highlighted gender bias against women and the attendant subordination of the women in the society. The repercussions of this bias have glaring implications on virtually all spheres of human endeavour. In Epochi and Etuwe's views, the society has overtime, particularly in Africa, "seen women's place and position as subordinate resulting in marginalization, trivialization and stereotyping of women are glaring aspects of our life". This experience abound all over the world even in civilized climes. ${ }^{10}$ It is on record as posited by Olaluwoye, that the "first medical school in America admitted women after 78 years. They were allowed to become members of the medical associations after 146 years. In the same vein, women were admitted after 325 years and 339 years in Havard and Notre Dame Universities respectively to read law. Even in literature, women made under masculine pseudonyms, such as Mary Evans (George Elliot), Charlotte Bronte (Cumer Bell) and others. ${ }^{11}$

However, in Western societies, fundamental changes occasioned principally, be the industrial revolution have greatly aided the independence of women, and created by industrial revolution have greatly aided the independence of women and created a platform for an egalitarian society with their male counterpart. Economically, many have also supported their homes and become breadwinners. In terms of education, a great number of women have been liberated from the suckles of illiteracy which hitherto held them captives of male chauvinism.

In Benue State, the situation and conditions of a typical Tiv woman still remain fragile. This is occasioned by opprobrious practices and cultural beliefs, which have consigned women to have home service positions as they are consistently used as household items or properties. This experiences and neglect basically, reinforces the high incidence of Toxemia of pregnancy and peurperium among Tiv women of Central Nigeria. It is a fundamental truth that men and women are physiologically different because, they differ in needs and priority, yet equity demands that both sexes have equal access and chances. But on the contrary inequalities exist in politics, employment, health care policies, education, decision making at all levels thereby creating hindrances to development. In Benue state for instance and Nigeria at large, female politicians are very few, in employment, they are restricted to particular jobs, in education, girls are neglected, rather the boys are fully trained, saying the woman's place is in the kitchen. The worse case scenario is in the area of decisions, both at home and the wider society. These experiences, created a consciousness which gave rise to the term feminism, gender equality, womanism, motherism e.t.c. thus, the history of feminism is the chronicles of women's resistance and opposition to patriarchy (male dominance). It is a protestant ideology, which upholds the emancipation of women from being subjected to stereotypical roles in the society.

Feminism as an organized political struggle and theoretical construct originated from the West and spread to other parts of the globe. Feminism as a theory locates the roofs of women oppression, domination and marginalization by their male counterpart in culture, traditional practices and social convention. Ezeigbo has effectively argued that inequality of sex is neither a biological nor a divine mandate but a cultural construct so it is viewed "as a social doctrine, which advocates that social, economic and political rights for women be the same as men". 12

The patrilineal character of the Nigerian society makes the approximation of feminist disposition a herculean task. In fact, feminism is accepted with prints of salt. It is confronted with heavy bias and misrepresented particularly by men who felt threatened with the way it is practiced elsewhere. The liberal form, which is introduced both in theory and practice in Nigeria and elsewhere in Africa seeks amongst other things, the transformations of major areas of women oppression such as the implementation of gender related health policies, the traditional family conceptualization of a woman, economic dependence, educational backwardness and absence in politics. This will hopefully bring about a just society where men and women will co-exist in equal dignity and love. This is captured succinctly in the United Nations publication by Kofi Anan, the former UN Secretary General when he said that "study after study has shown that there is no effective development strategy in which women do not play a central role when women are fully involved, the benefits can be seen immediately. Families are healthier and better fed; their income, savings and reinvestments go up. And what is true of families is also true of communities and in the long run, of whole countries".

The application of this framework has highlighted the plight of the Tiv women viz a viz their access to health facilities and proper implementation of health policies that are feminine. In this study, concerns have been raised about gender bias as regard access to medical care and the quality of care received. 


\section{Discussion}

Health challenges before African rural women

One of the major challenges of achieving improved health policies for both men and women in Nigeria stems from miscalculations in the implementation state. Consequently, the various strategies which have been enunciated for achieving an integrated gender-based health programmes have been poorly implemented. Reason has been that most often, some of the policies are conceived with the aim of achieving improved health without recognition of the other dimensions of growth and poverty, and health education.

The cumulative effect of this has been the short span of life expectancy of Nigerians. ${ }^{13}$

Other challenges of gender health integration and implementation can be evident in problem of coordination and application of resources flows for health. At all operational and governance levels of the health care system, it still remains unclear where the leadership for resource mobilization, coordination and targeting lies and where accountability for outcome is best placed. This rings true not only for programmes supported by Nigeria's development partners but also for its key priority programmes. Between the Federal Ministry of Health, its operating departments and parastatals have been central to the health reform process. Resources flow channels remain top down, duplicative and crossed and indication of near absence of clear channels on health planning and resource allocation. The effect of this on the collective and integrated health development becomes difficult.

\section{Health Policy before 2004}

The Health Sector Reform Programme (HSRP) identifies health as an entry point for poverty reduction and national efforts to combat under-development. It must be recalled that the post-independence era, especially the period between 1980-1999, the country was replete with decline economic fortunes sequel to the implementation of SAP. It should be noted that as a condition, SAP emphasized reduction on public expenditure on education and health. As a result of reduced expenditure and attention on the health sector, diseases that were earlier on declared eradicated resurfaced. Diseases such as chicken pox, small pox and cholera became so prevalent. This problem was worsened by the policy of retrenchment which reduced the quality of life of the people to the barest minimum. This was the background against which the NEED/SEEDS initiatives were launched. The NEED/SEEDS seek to address these problems through a systematic framework that focuses on good governance and growth of the non-oil sector of the economy and to do so in a manner that would engender policy coordination between the tiers of government. That is to say that, the proposed improvements in health were designed in the context of the National Economic Empowerment and Development Strategy (NEEDS) and health was given priority in both policy and investment actions at all levels of governance. Health sector reforms were identified in the context of the earlier described sick and moribund state of both health systems performance and service delivery effectiveness, characterized by difficulties in internal, vertical and horizontal relationships of the FMOH and its parastatals, limited coordination of health resources and investment in health at all levels, poor and often times dilapidated infrastructure and equipment maintenance, a de-motivated workforce whose capacity for service delivery was often hampered by non-availability of the required equipment and supplies as well as a high prevalence of fake, substandard and unregistered drugs.

The health sector reform process was participatory led by the Federal Ministry of Health and drawing input from a broad range of stakeholders, including development partners and state level implementers and policy makers through the National Council on Health $(\mathrm{NCH})$. The overall mission of the health sector reform or National Health Policy was to undertake a government-led comprehensive reform aimed at strengthening the national health system to enable it deliver effective, efficient qualitative and affordable health services and thereby improve the health status of Nigerians and the health sector's contribution to breaking the vicious circle of ill-health, under-development and poverty. The overall goal of the MSR was to improve health outcomes and fast-track Nigeria's attainment of the health-related MDGS, particularly, reduction in infant, child and neonatal mortality rates as well as maternal mortality ratio. The pathway for improvement drew from those identified by the World Bank in achieving the MDGS including reform in government policies and actions.

\section{Health sector reform: a case study}

Many countries are now going through a process of health sector reform. Though some attention has been focused on the implications of these developments for the poorest people, few policy makers have taken gender issues into consideration. There is now

increasing evidence that as a result, health sector reform may be increasing rather than reducing gender inequality.

Although information on these effects is still sparse, it is clear that gender issues should be a central concern in health sector reform for several reasons. First, women are found disproportionately among the most vulnerable population groups. Hence economic and financial changes in service delivery may have a disproportionate effect on them. Second, access to and utilization of health services are heavily influenced by 
cultural and ideological factors such as low valuation of the health of women and girls and this majority of health workers. Unless attention is paid to gender issues of this kind, health sector reforms may worsen women's overall position by comparison with that of then. The following illustrate the sorts of questions that need answering before equitable policies can be enacted.

What would be the impact on male and female health workers of reforms in health care bureaucracies?

Would decentralization improve access to health care or further marginalize the most vulnerable groups? workers?

How would improvements in the functioning of national ministries of health affect male and female

What are the implications of different financing options for gender inequalities in access to care?

How would managed competition affect equality and access?

Are women's health needs more or less likely to be met in a mixed economy of care operated

in collaboration with the private sector?

\section{National Insurance Scheme/Policy}

After a prolonged period of incubation, the National Health Insurance Scheme was launched in 2005. Designed to provide care in the first instance for civil servants and Nigerians in formal employment, the NHIS has expanded the scope of its operations significantly and by May 2006, it had over 800,000 people registered with projections to hit coverage by three million people by the end of the same year. The high level of out-ofpocket or household expenses on health pose particular challenges to policy makers in convincing and redirecting the population to use this resource cost effectively and in a socially responsible way. While Community-Based Health Insurance (CBHI) may offer an option for harnessing this level of household expenditure, population resistance to government led contributory mechanisms proposed by the NHIS may limit its broader uptake through this channel. The contributions of the community and mutual and/or health cooperatives managed by both for-profit and non-profit private organizations may also offer viable and sustainable options and need to be explored. ${ }^{18}$

\section{Bias in health policy}

Women provide the biological basis through which people are born into the world. Therefore, women's capacity to conceive and give birth means that their reproductive health care, needs additional affection to those of men both in sickness and in health. However, experience has shown that, policies have not been conceived specifically to carter for the health care of women even in the face of this reality. Also, it is no doubt that women do not have equal access to credit facilities in Nigeria. This is an aspect of economic inequality, and by economic inequality, it means that women have difficulty in acquiring the basic necessities for a healthy life. Of course the degree of their deprivation on the community in which they live but the "feminization" of poverty remains constant theme. Cultural devaluation is also important though difficult to measure or even to define. Because they belong to a group that is seen by society to be less worthwhile, many women find it difficult to develop positive mental health. This process begins in childhood with girls in many cultures being less valued than boys and continues into later life where 'caring work' is given lower status and less rewards. The gender inequalities are further reinforced by women's lack of power and the obstacles they face trying to effect social change. In spite of these forms of inequalities, the health policy makers have not being able to make appropriate laws in terms of women having equal access to credit facilities for a healthy life. Also, laws have not being developed to do away with the illusion or idea that girls are inferior to boys. This makes it difficult for them (girls) to develop positive mental health. Furthermore, the 2003 NDHS reported that 54 percent of urban women and 66 percent of rural dweller had experienced violence while as high as 65 percent of women justified violence against themselves. ${ }^{19}$ On the other hand, the Federal Ministry of Women and Social Development (FMWASD), in 2007, reported that violence keeps women in poverty, jeopardizes their health and limits their capacity to take advantage of economic opportunities with serious consequences for them and children. In spite of the clean provisions of CEDAN that prohibits violence against women the failure of the country to domesticate this convention means absence of a legal platform for victims of domestic violence. Clearly, the health policy makers in Nigeria have not recognized this with the view to embarking on programmes that will enlighten the people and at the same time, liberate the women from this shackle of oppression, suppression and depression which has made it impossible for them to develop positive mental health apart from the physical injury incurred in the cause of the violence. Health policy makers have not made room for compensation for women who falls victims of domestic violence occasioned by men in the domestic setting. This if provided for, would to some extent guarantee the health security for women.

The inglorious silence of health policy makers on child marriage is yet another aspect of bias in health policy. According to UNICEF, the maiden age at marriage for Nigerian women was 17 in 2005. In Kebbi State the age was about 11 though marriage of children as young as 10 years is still common (ibid). The same study 
shows that $43 \%$ of Nigerian women marry by the age of 18 . Child marriage has severe negative implications on the child. ${ }^{21}$ Consequences of child marriage include increased risk of maternal complications such as prolonged labour, hypertensive disease of pregnancy and obstetric fistula. It is rather unfortunate that in spite of the health dangers inherent in child marriage, national policy makers have not sufficiently addressed this problem in the interest of the health system of the young women:

If hunger is degrading, the combination of hunger and squalor is dehumanizing. Nearly twenty percent of the population, having to make their living in urban areas find themselves in this plight. Overcrowding, no water supply, open drains, refuse heaps and indescribable filth around the house. Here they have to raise their children and watch them die ${ }^{.22}$

\section{Effects of Toxemias on Tiv Women}

During the first stage of this complication which is usually referred to as the pre-eclampsia, and which occurs usually during three months of pregnancy and during the peurperium, the affected patient develops high blood pressure, there is also a change in the kidney, which causes the patient to lose procaine in urine. A woman affected by this disorganization in pregnancy also develops edema, (swollen leg). This situation is commonly found among Tiv women who are having their first pregnancy. It does not have to apply only to those who are poor in the society but can also affect the educated women. The difference between an educated and an uneducated woman affected by it is that, the enlightened woman knows when and how to go to the clinic for medical check-up, plus the appliance of the drugs while an uneducated one stays just at the mercy of

God. During this period, the blood pressure raises form 140/90 to 160/110. The causes of this women health problem remains a problematic issue but can be traced to increase resistance in the arterioles with vasospasima affecting the brain, liver and kidneys as well as retention of sodium in the tissue. In severe cases, peuperuim, Oedema of the ankles which may affect the face and hands is developed, and shows serious signs or symptoms of ailment. Symptoms of pre-eclampsia such as sharp rise in the blood pressure, more increase in peuperium, increase in Oedema and severe frontier headache. If not treated the high blood pressure may continue to rise and the patient may develop fits (convulsion) and die. In ecclesia stage, the condition becomes acute, characterized by convulsion and coma and then death, if not treated.

The situation in Gbemacha was more pathetic, here is an area of about $17 \mathrm{~km}$ away from Gboko town, with a population of about four hundred thousand $(400,000)$ people with only one Health Clinic without drugs, two staff and a dilapidated building without any good road, no water, no electricity and no hospital. Communication is therefore always a problem and vehicles from Gboko only get to this place on market days. During my last holiday I happened to witnessed one of the most horrifying human problems I have ever seen. Here was a woman who had a six months old pregnancy and the pregnancy developed toxins.

She had complications and was about to give an untimely birth. There was no doctor to treat her and no hospital around, I happened to have been around waiting for a vehicle to Gboko with this woman, and on our way due to gallops she became unstable, she developed highs stomach and pregnancy trouble in the abdomen and before we could reach Gboko town, she died in pains. Yet we have the Ministry of Health responsible for providing health facilities, a Ministry of Works andTtransport responsible for providing good roads to our own rural people. There is also acute shortage of ambulances for emergency cases.

It is therefore common to hear of death due to pregnancy complications in Benue State. For instance, the table below indicates high rate of these complications which ranges from toxemias of pregnancy to other complications of pregnancies like abortions.

Table 1:Showing the complications of pregnancy and the peurperium in 1980 before the sliptting of

Code
\begin{tabular}{|l|l|l|l|} 
pregnancy related complications & No of cases & No of deaths \\
\hline A112 & Toxemias of pregnancy and the peurperium & 186 & 3 \\
\hline A113 & Hemorrhages of pregnancy and childbirth & 241 & - \\
\hline A114 & Abortion induced for legal indication & 11 & - \\
\hline A115 & Spaces of child birth and the peurperium & 215 & - \\
\hline A116 & Other complications of pregnancy and the peurperium & 1895 & 72 \\
\hline A117 & Delivery without mention of complication carried forward & - & - \\
\hline A118 & Other and unspecified abortions & 1996 & 4 \\
\hline
\end{tabular}

Source: Health Services Management Board Makurdi

The government places high priority on the provision of health facilities to the people. For instance according to the government publication, "Contracts have been awarded for construction of general hospitals in all the local government headquarters where none exists.” But when I visited these hospitals as far back as $1^{\text {st }}$ March, 1982, I found out that for most of the contracts awarded, either work had been abandoned or still under construction and the buildings already developing faults. The study found out that the one at Katsina-Ala was under construction, 
while the one at Vandeikya either had been neglected or work abandoned by contractors, who receive huge mobilization fees.

When I asked the planning officer in-charge of the ministry of health, he told me that they don't have the dates, where these hospitals and clinics have been allocated and that "we only deal with contract award after which we handle the business to the H.M.B.”.

this goes to a large extent to indicate how policy makers in Nigeria are only interested in awarding contracts in order to get $10 \%$ kick backs.

\section{Government management of women health problems and implementation of health policies}

Explaining government problems, an official of the H.M.B. narrated to me how they face acute financial problems. According to government official, apart from the shortage of medical staff, "the government is faced with the problem of inadequate fund," which to me I consider as the inefficiency and misappropriation of fund for wasteful projects that don't serve the interest of the common man and perhaps the devilish attitude of some government officials who tend to place more emphasis on embezzling the little amount got form the toils of the suffering masses. If not for lack of proper planning the state government, between the months of January to July 1981 received the total statutory allocation of N151,431,414.42k and before the expiration of that month the government was placed in a financial crisis to an extent that she could not even afford to pay the nurses their increased benefits. With this level of administrative laxity on the part of our policy makers it is often more difficult to effectively carry out an effective health programme for the people. A Teaching Hospital which was promised for the state in 1976 only got started during the reign of Governor George Akume but up to this material time the hospital has not been completed. This indecision devised especially by our politicians to win power during the 19791999 and 2007 electioneering campaigns are devised just to win and help those who are on the top strata of the society. This is because majority of the big business men, top bureaucrats and politicians reside in Local Government Headquarters and the government health policy is to provide hospitals that are ill-equipped and poorly constructed at exorbitant rates. Even when the hospitals exist the rural dwellers are not opportune to attend them because their level of education is low and as such don't know the importance of modern hospitals especially pregnant women.

Table 2 :Showing the number of health Institutions in Benue State by type and Local Government 1980 before the splitting of the state in 1993

\begin{tabular}{|c|c|c|c|c|c|c|c|c|}
\hline $\begin{array}{l}\text { Name of } \quad \text { Local } \\
\text { Government }\end{array}$ & Hosp. & $\begin{array}{l}\text { Rural } \\
\text { Health } \\
\text { Centres }\end{array}$ & $\begin{array}{l}\text { Maternity } \\
\text { Clinic } \\
\text { Centres }\end{array}$ & HC & DP & DC & GHO & TOTAL \\
\hline ANKPA & 1 & 2 & 1 & 5 & 11 & - & 1 & 21 \\
\hline BASSA & - & - & 3 & 3 & 2 & - & - & 8 \\
\hline DEKINA & 3 & 1 & 5 & 2 & 4 & - & 16 & 16 \\
\hline GBOKO & 2 & - & 7 & 7 & 20 & - & 1 & 37 \\
\hline GWER & 1 & - & 3 & 1 & 5 & - & - & 10 \\
\hline IDAH & 2 & 1 & 8 & 4 & 10 & - & 1 & 26 \\
\hline K/ALA & 1 & 1 & 8 & 3 & 6 & - & 1 & 20 \\
\hline KWANDE & - & - & 13 & 4 & 6 & - & 1 & 23 \\
\hline MAKURDI & 3 & 1 & 5 & 9 & 7 & - & 1 & 26 \\
\hline OJU & 1 & - & 1 & 2 & 3 & - & 3 & 7 \\
\hline OKPOKWU & 1 & - & 1 & 2 & 3 & - & - & 14 \\
\hline OTUKPO & 3 & 1 & 6 & 2 & 10 & - & 1 & 22 \\
\hline \multirow[t]{2}{*}{ VANDEIKYA } & 1 & - & 11 & 2 & 6 & - & - & 20 \\
\hline & 19 & 7 & 73 & 45 & 98 & - & 26 & 250 \\
\hline
\end{tabular}

Source: Benue State Health Management Board Makurdi.

Note: It is however imperative to note that although the above figures are high, moist of the hospitals, clinics, dispensaries, maternity centres etc are established by either missionaries or voluntary agencies, hospitals built during the colonial days take care of the colonial masters who were here in Nigeria for their exploratory expeditions.

The management of this women health problem has been one of the most difficult and pressing situation in Benue State. Normally, all patients with this condition should be admitted in hospital, rest in bed, Oedema gagged, urine tested and measured etc. They are supposed to be tested every four hours. There should also be poison of adequate drugs such as anti-hypertensive drugs and sedative drugs, given special diet, the fluid intake and diveticas (anti -hypertension drugs like Aldomet). In the whole of Makurdi town there is only one government hospital and it is this hospital that is meant to serve the surrounding rural areas. With a population of over 267,000 people the condition becomes

pathetic. ${ }^{24}$ At the hospital it was discovered that out of the 250 patients waiting for treatment, there was only one physician to attend to them. Some were gnashing their teeth 
in pains, while some were crying for help. But the situation was beyond the physician's control, it only shows the level of government insensitivity to the health problems affecting the people coupled with the colonial hangover of administrative policy of indecisions, which are still a characteristic of our governments today.

In situations where the physician diagnoses or prescribes drugs for the affected patient they cannot afford to buy or get these drugs in the government hospitals. For one, the level of corruption among government officials is high. In 1981 the "New Nigerian", the Benue State Commissioner for Health indicated that police escorts would have to accompany all vehicles carrying drugs to the state capital. These government officials either sell part of the drugs or equip them into their personal medical stores. Apart from these problems, we have the problem of class. We find out that while the wives, relations, daughters and mothers of commissioners, big civil service officials, high ranking army officials and businessmen have easy access to maternal health clinics, the poor ones who do not have connections are always rendered helpless. The transportation system is not good. While most of our rural areas lack good roads to travel to Makurdi Metropolis for antenatal medical health care; top government officials always station in their homes big Mercedes Benz Cars for refreshment, 504 station-wagon for taking their children to school, 504 salon for taking the wife to the market and these things are displayed without regards to the agony of the poor,. The big businessmen in the town and top government official's wives and relations can afford to travel either by road or air to Zaria (a distance of 400 kilometres) to attend the Ahmadu Bello University Teaching hospital. This is the more reasons why they would struggle to establish domestic stupors to link important places for their businesses. The socio-political health problem of women is interwoven with the family background. There are some women who lost their husbands during World War II and the Nigerian Civil War. The latter being a result of colonial and imperialist manifestation that made the black man fight wars, which did not concern them. And the aftermath is high rate of social and economic problems. Most of these problems would have been averted with proper planning but, there is administrative deficiency. For instance the level of education and enlightenment among the women remains at the lowest level. For those who are educated according to what the doctor told the researcher, "know the implications of pregnancy as such take necessary steps to have antenatal treatment by constantly coming to the hospital for medical check-up" while the uneducated one feel unconcerned. For instance, according to P. York and N.L.B. Materu in an article titled", Patient Medication Compliance in a Developing Country, some problems exist such as "Illiteracy, lack of trained medical and paramedical staff as well as existing ideological views with respect to medicine taking". 25 This is a typical indication of what obtains in the developing countries; most of these illiterate women do not know how to administer drugs and some of them do not feel that going to the hospital for treatment is not necessary.

Some societies even have norms and taboos, which prohibit them from going to the hospital, so we find a problem of illiteracy culminating with the problem of anti-clinical taboos. Apart from this as I earlier on mentioned in most cases the diets which are supposed to be given to the affected women is not always available in the hospital and because of the low income of the peasantry the pregnant woman finds it difficult to eat even ones in a day-talk more of eating prestigious items such as eggs. Most of them therefore, consider eggs as a delicacy meant for the rich such that when a black man acquires eggs for his use, you are often regarded as being at the top of the social ladder.

Similar concerns have been raised about gender bias in access to medical care and in the quality of care received. There is considerable evidence to show that women experience gender-related constraints on their access to health services and that this affects the poorest women in particular. The obstacles they face include; lack of culturally appropriate care, inadequate resources, lack of transportation, and absence of alternative care for their families and sometimes the refusal of their husbands to give permission for medical treatments outside of their environment. Of course limited public expenditure on health care will affect men as well as women but in conditions of scarcity it is often the females in the family whose needs are given the least priority.

If they do gain access to health care, there is also evidence that the quality of care women receive is inferior to that of men. Too many women report that their experiences are distressing and demeaning. Medical knowledge is too often presented as inevitably superior, giving women little opportunity to speak for them or to participate actively in decision making about their own bodies. These problems are reflected particularly in the context of reproductive services where dehumanizing and insensitive treatment can affect women's willingness to return. This development justifies the feminism theoretical framework adopted for this study which posits that women all over the world face marginalization, trivializations and stereotyping based on their Gender. The patricianly character of the Nigerian society in particular makes the approximation of feminist disposition a big task 
Table3: Showing nature of Pregnancy related diseases common to Tiv Women.

Hospital: Gboko General Hospital

\begin{tabular}{|c|c|c|c|c|c|c|c|c|c|c|c|c|c|c|c|}
\hline $\begin{array}{l}\mathrm{g} / \\
\mathrm{n}\end{array}$ & Pregnancy disaseas & $\begin{array}{l}200 \\
0\end{array}$ & $\begin{array}{l}200 \\
1\end{array}$ & $\begin{array}{l}200 \\
2\end{array}$ & $\begin{array}{l}200 \\
3\end{array}$ & $\begin{array}{l}200 \\
4 \\
\end{array}$ & $\begin{array}{l}200 \\
5\end{array}$ & $\begin{array}{l}200 \\
6\end{array}$ & $\begin{array}{l}200 \\
7\end{array}$ & $\begin{array}{l}200 \\
8\end{array}$ & $\begin{array}{l}200 \\
9\end{array}$ & $\begin{array}{l}201 \\
0\end{array}$ & $\begin{array}{l}201 \\
1\end{array}$ & $\begin{array}{l}201 \\
2\end{array}$ & $\begin{array}{l}\text { Tota } \\
1\end{array}$ \\
\hline 1 & Abortions & 106 & 100 & 56 & 65 & 43 & 43 & 24 & 18 & 5 & 34 & 22 & & 2 & 509 \\
\hline 2 & Angemia in pregnancy & 2 & 5 & 3 & 2 & & 1 & & & & 1 & & & & 14 \\
\hline 3 & Malaria in pregnancy & 3 & & & & & & & & & & & & & 3 \\
\hline 4 & PID in pregnancy & 1 & & & & & & & & & & & & & 1 \\
\hline 5 & Hamonghage & 1 & 1 & & & & & & & & & & & & 2 \\
\hline 6 & PID & 1 & & 1 & 4 & 2 & & & & & & & & & 8 \\
\hline 7 & RUDTEREDECTOPIC & 3 & 1 & 7 & 1 & & & 2 & & & & 1 & & & 15 \\
\hline 8 & RUPTURED PLACEWTA & 1 & & & 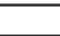 & & & & & 1 & 2 & & & & 4 \\
\hline 9 & ECTOPIC GESTATION & 3 & 1 & & & 2 & 1 & & 1 & & & & & & 8 \\
\hline 10 & $\begin{array}{l}\text { POST-PORTION } \\
\text { HAEMORGHAGE }\end{array}$ & 1 & & & & & & & & & & & & & 1 \\
\hline 11 & ECTOPIC PREGNANCY & 1 & & 2 & 2 & 4 & & 2 & 2 & 1 & & 1 & & & 15 \\
\hline 12 & MAL_ARIA & 4 & & 6 & 5 & 3 & 2 & & & & 1 & 1 & & & 22 \\
\hline 13 & BLEEDING & 1 & & 1 & 2 & & & & & & & & & & 4 \\
\hline 14 & $\begin{array}{ll}\text { RUPTWEWD } & \text { IN } \\
\text { PREGNANCY }\end{array}$ & 1 & & & & & & & & & & & & & 1 \\
\hline 15 & HW & 1 & & & & & & & & & & & & & 1 \\
\hline 16 & UTI & 2 & & & & 5 & 1 & & & & 1 & 1 & & & 10 \\
\hline 17 & ACUTE MALLARIA & 1 & & & & & & & & & & & & & 1 \\
\hline 18 & OVARIAN MASS & 2 & & & & & & & & & & & & & 2 \\
\hline 19 & VAGINTES & 2 & & & & & & & & & & & & & 2 \\
\hline 20 & MOLAR PREGNANCY & - & 1 & & & & & & & & & & & & 1 \\
\hline 21 & POSTILARTUM HAEM & - & 1 & & & & & & & & & & & & 1 \\
\hline 22 & PPH & - & 3 & 1 & & & & & & & & & & & 4 \\
\hline 23 & AUTOMAL_ARIA & - & 1 & & & & & & & & & & & & 1 \\
\hline 24 & HEPATTTIS & - & 1 & 1 & & & & & & & & & & & 2 \\
\hline 25 & PNEUMONIA & - & & 1 & & & & & & & & & & & 1 \\
\hline 26 & GASTROENTERTIS & - & & 1 & & & & & & & & & & & 1 \\
\hline 17 & PUD & - & & & 5 & & & & & 1 & & & & & 6 \\
\hline 28 & ADOMINA PAIN & - & & & 1 & & & & & & & & & & 1 \\
\hline 29 & $\begin{array}{l}\text { HEPTCEPTOSPLEMIEGAL } \\
\text { LY }\end{array}$ & - & & & 1 & & & & & & & & & & 1 \\
\hline 30 & BULKY UTERUS & - & & & & & 1 & 1 & 1 & & & & & & 3 \\
\hline 31 & UTERINE FIROID & - & & & & & & & 1 & 2 & 1 & & & & 4 \\
\hline 32 & UTERINE PERFORATTON & - & & & & & 1 & & & & & & & & 1 \\
\hline 33 & SEPTIC ABORTION & - & & & & & 1 & & & & & & & & 1 \\
\hline 34 & $\begin{array}{l}\text { THREATENED } \\
\text { ABORTION }\end{array}$ & - & & & & & & & 2 & & & & & & 2 \\
\hline 35 & OVARIAN CYST & - & & & & & & & & 1 & 1 & & & & 2 \\
\hline 36 & TAH & - & & & & & & & & 1 & & & & 1 & 2 \\
\hline 37 & CYST IN PREGNANCY & - & & & & & & & & 1 & & & & & 1 \\
\hline 38 & JAUNDICE & - & & & & 1 & & & & & & & & & 1 \\
\hline 39 & RTI & - & & 1 & & & & & & & & & & & 1 \\
\hline 40 & HYPERTENSION & - & & 1 & & & & & & & & & & & 1 \\
\hline 41 & VOMITTING & - & & 1 & & & & & & & & & & & 1 \\
\hline 42 & LOBOR PNEUMONIA & - & & 1 & & & & & & & & & & & 1 \\
\hline 43 & SALPINGITIS & - & & 1 & & & & & & & & & & & 1 \\
\hline 44 & BLEEDING P.V & & 2 & & & & & & & & & & & & 2 \\
\hline
\end{tabular}

Sources: form BSHMB/STATO/10

Benue State Hospital Board-Health statistics (HMIS) unit

\section{Recommendations}

- $\quad$ The solutions to these problems are indeed another aspect of this study. We can therefore talk of long term and short term solutions, the long term solutions include among other things the adequate education of our women so that they take advantage of these medical facilities that though are in limited quantity would help to improve their pregnancy and health conditions. The government should improve medical facilities, by establishing more hospitals and maternity clinics in the rural areas. An efficient and mobile system of rug delivery to the rural areas should be set in motion. ${ }^{26}$ The government should establish more schools to train midwives and post them right into the rural areas to help midwives and post them right into the rural areas to help our poor and needles, which always suffer from these pregnancy complications and the puerperium.

One of the greatest financial problem of our people is that majority of us do not find employment even after secondary and University Education. The embargo on employment subsists while at the same time the government has approved more gubernatorial Liaison Officers, Commissioners and Political Officeholders. This situation contradicts policy decisions of government. More employment opportunities should be created to solve our financial problem so that even when pregnancy complication is disturbing a poor woman who works or has a husband who is a labourer and receiving a little income can afford to seek medical redress. Finally, we should be more patriotic in our public offices by being fair to all and placing the welfare of women on the priority list. Corruption is a social evil that need to be discouraged. The irony of public office is that, here in Nigeria one 
who receives bribe and enriches himself through corrupt means is usually seen as a hero in the society while the ordinary armed robber who steals is hanged. Usually, government officials misappropriate funds meant for the provision of basic health amenities like maternity clinic to foreign banks while the poor continue to die of starvation and poverty.

\section{- $\quad$ Mianstreaming Gender In Medical Research}

As we have seen, gender inequalities in the wider society are also reflected in the way medical research is carried out. If this is to be changed, women's need and desires must have a more prominent place in the research process. These will not happen by accident. Rather, a formal set of policies will be needed to ensure that their interests are represented. Only then will health related research reflect the interests of all its potential users equally.

\section{- $\quad$ Measuring Women's Health}

ne of the most basic problems facing many policy makers is lack of specific information on the situation of women. The failure to separate women from men in national and regional statistics can make it difficult to plan effectively to meet the particular needs of either group. It is essential therefore that data is collected about both sex and gender differences in health status and that the results are clearly presented for easy use. The conceptual framework for this data collection process must be appropriate to the setting in which it is being used and must also recognize the diversity of women's experiences over the lifespan.

Older women and young girls for example, may have particular health problems, making it essential that factors such as their nutritional status or their access to health care are routinely monitored. This will require the development of appropriate indicators for measuring different aspects of their health and quality of life. Other groups of women whose vulnerability may require special attention include those who are refugees or migrants, those who are bringing up children include those who are coning with chronic disease or long term disabilities. $^{27}$

In many developing countries, the lack of data on women's health reflects in part the very limited nature of the vital registration system, which affects both sexes. However, this is often compounded by a failure on the part of the relevant authorities to recognize the importance of gender issues and a lack of understanding of the complex social pressures that may render women's health problems invisible. In the case of maternal mortality for instance, a wide range of religious, cultural and social factors can contribute to serious underreporting. New methods have now been developed for identifying those cases that are missed and this need to be used routinely by those responsible for monitoring community health. Similar problems are evident in relation to the identification and measurement of domestic violence. This represents a huge public health problem which has not yet been adequately documented. If this knowledge gap is

\section{- Identifying Gender concerns in the policy Environment}

If the goal of developing gender-sensitive policies is to be achieved, this needs to be built explicitly into original objective of the programme in a way that can be used later for evaluation purposes. This will require a preliminary analysis of the context in which the policy will be operating and a clear understanding of the gender issues involved. This may be a relatively simple operation comparing the numbers of males and females in the target population and assessing the gender patterns in current service use. However, the analysis will usually need to be taken a stage further to make sense of the gender relations between individuals and groups being counted.

The questions to be asked will vary depending on the type of policy being developed but in most health care contexts they should include some of the following

Do gender differences in daily life expose women and men to different kinds of health risk?

Can any differences be observes in the quality of care women and men currently receive?

Who currently controls access to health related resources and do the allocation criteria take into account the different needs of men and women?

These broader contextual issues may sometimes be difficult to map but unless they are women into the implementation process at all stages the resulting policies will not be sensitive to women or men in their approach and inequitable in their effects. This can be illustrated by reference to some of the gender-related problems that have arisen in the process of health sector reform.

\section{- Putting Gender issues into the Planning Process}

If gender inequalities in health and health care are to be properly identified and tackled women themselves will need to be more involved in the design, implementation and evaluation of services. Because of 
the relative absence of women from most of the important arenas of decision making, special care may have to be taken to ensure that their views are heard. The most appropriate forms of consultation will vary with the circumstances but may include either discussion with representative groups or direct consultation with potential users. If the planning process is to be as participatory as possible and the goal of greater equality is to be realized in practice there must be a serious commitment to these aims at the highest levels of government. ${ }^{29}$ This is best demonstrated through the creation of a national or regional policy framework within which both the planning process itself and delivery of services can be located. Though there is no single model for such a framework, a range of options already exist in countries

\section{- The importance of capacity building for gender sensitive services.}

Once plans have been drawn up, the effective operation of the service will require a strategy for educating health workers and managers so that they understand better the significance of gender issues in health. Capacity building programmes need to be designed for both make and female workers and they need to focus not just on 'women's issues' but on the wider question of gender itself. They may include broadly based 'gender awareness' courses and also more detailed briefings on gender-related topics not generally included in medical, nursing or other curricula. ${ }^{30}$ It is important that these programmes be culturally appropriate to the settings in which they are to be used but a number of models already exist which can be sued as the foundation for their development. Courses of this kind need to be provided for health workers who already qualified but they also need to be formally built into the curriculum for all those undertaking health care education and training. Medical and nursing curricula in particular need to be very carefully shaped if gender issues are to be properly embedded in the future planning and delivery of services.

\section{Conclusion}

In conclusion, the Toxemias of Pregnancy and the pueperium is a dangerous health problem among Tiv women and is common not only in Benue State but even in the advance countries of the world. What matters however is the level of approach to solving this women health problem. Here in African, lack of education, taboos, inadequate provision of amenities, lack of sound financial background, embezzlement and people's attitude toward medical treatment contributes to the development of Toxemias through the pre-exclampsia to eclcampsia stages. This development consequently, creates serious hypertension, oedema of the legs, convulsion and inevitably resulting to death. In the advanced countries, due to adequate antenatal facilities, sound medical staff, sound financial background and high level of women enlightenment concerning complications in pregnancies, their women continue to enjoy sound health and even when toxemias develops in a woman, it is quickly treated without bottlenecks. The only solution to these problems is for our policy makers to develop radical policies that would uplift our down-graded women's health facilities especially in the rural areas. The whole system need to be reviewed.

\section{References}

[1]. Ahmad, K. (2000). Women suffer first from lack of health-care services. Lancet 356 (9235): 1085.

[2]. Ajao, E. (1986). Indigenous beliefs and practices about pregnancy and delivery among womeninselected villages in Ife Division. Unpublished doctoral dissertation, Obafemi Awolowo University, Nigeria.

[3]. Aliogo; J. E. (2009), Nigeria: Past Present and Future Coment Affairs; Enugu: De JoePublication Communication Ltd. Pp12

[4]. All datas used are official documents from the Benue State Health Services Management Board.

[5]. Anunobi, F.O. (2003). The role of women in economic and political development incontemporary Africa. Negro Educational Review 54(3): 61-77.

[6]. Attah, B. (1980) "Patient Medication Compliance in Developing Countries" Journal of Clinical and Hospital Pharmacy Vol. 5 no. 4, Blackwell Scientific Publications: Oxford London.

[7]. Atim, T. (1997) The Search for a Viable Benue State, Makurdi, Satos Press.

[8]. Awake, (2003); Motherhood: Does it take a Superwomen? March $23^{\text {rd }}$ Barbara, F. Dobson,P. (1974) Bailliere's Nurses Dictionary $18^{\text {th }}$ Edition, English Language Book Society and Bailliere Tindall London.

[9]. Basher, M. (2012) “100m Nigerians in Absolute Poverty,” Bureau say; Daily Trust,Truesday February 14, p1

[10]. Cohen, M. R. and Manion, L. (1980), Research Methods in Education UK: CroomHelm pp26.

[11]. Defo, B.K. (1997). Effects of socio-economic disadvantage and women's status onwomen's health in Cameroon. Social Science and Medicine 44(7): 1023-1042.

[12]. Doki, A. G. (2003) Images of Womanhood in Tiv Society: A critical Appraisal. (ed) in Review of Gender studies in Nigeria Vol. 2

[13]. Dung, P. S. (2003) Women and the Management. The Nigerian state: A Reflection on the past, present and the future (ed) in review of Gender studies inNigeria Vol. 2.

[14]. Dura, M. M. (2005). Tiv customary law and women's Rights within the family (ed) The Journal of Family development, Vol. 2 No 1 pp 77-90

[15]. El Hadi, A.A. (2000). Female genital mutilation in Egypt. In: M. Turshen (ed.), African Women's Health, pp. 145-166. Asmara, Eritrea: Africa WorldPress, Inc.

[16]. Erb-Leoncavallo, A.M. (1997). Uneven progress for African women. AfricaRecovery 10 (4). Retrieved December 9, 2004, from

[17]. Epochi, O. and Etuwe, R. (2009): Unonasking Gender Bias Towards Positive Development: The Feminist Theater Approach; Abraka: Delsu Ivest Nigeria Limited: pp23

[18]. Epochi, O. and Etuwe R. (2009) op'cit pp24. 
[19]. Epochi, O. and Etuwe R. (2009), Unmasking Gender Bias Towards positive Development: The Feminist Theatre Approach

[20]. Ezeigbo A. (1996) Gender Issues in Nigeria: A Feminism Perspective. Lagos; University of Lagos Press. http://www.un.org/ecosocdev/geninfo/afrec/1997/beijing.htm

[21]. Flowers, C. (1967) Empirical management of Toxenias of pregnancy: Ostretic, and Gynecology - Vol. 19- issue 5 - pp 049-658

[22]. Global Health Council (2005). Women's Health. Retrieved December 9, 2004, from http://www.globalhealth.org/view_top.php3?id=225

[23]. Goosen, M., and Klugman, B. (eds.). (1996). The South African Women's Health Book. p.155. Cape Town: Oxford University Press. Cited in: M. Turshen (2000), Women's mental health. In: M. Turshen (ed.), African women's Health, pp. 83-106. Asmara, Eritrea: Africa World Press, Inc.

[24]. Karim, Q.A., and Frohlich, J. (2000). Women try to protect themselves from HIV/AIDS in Kwazulu-Natal, South Africa. In: M. Turshen (ed.), African Women's Health, pp. 69-82. Asmara, Eritrea: Africa World Press, Inc.

[25]. Khosia, P. (2003). Women's environments: The struggle for a healthy \& sustainable planet. Women \& Environments International Magazine 60/61: 9.

[26]. Leslie, J., Essama, S.B., and Ciemins, E. (2004). Female nutritional status across the life span in sub-Saharan Africa. 2. Causes and consequences. Food and Nutrition Bulletin 18(1). Retrieved December 9, 2004, from http://www.unu.edu/unupress/food/V181e/ch2.htm

[27]. Margaret F. M. (1971) Textbookfor Midwives, English Language Book Society and Churchill Livingstone, London, Longman Group Ltd.

[28]. Manjate, R.M., Chapman, R., and Cliff, J. (2000). Lovers, hookers, and wives: Unbraiding the social contradictions of urban Mozambican women's sexual and economic lives. In: M. Turshen (ed.), African Women's Health, pp. 49-68. Asmara, Eritrea: Africa World Press, Inc.

[29]. Mebrahtu, S. (2000). What we need is timely assistance. In: M. Turshen (ed.), African Women's Health, pp. 27-47. Asmara, Eritrea: Africa World Press, Inc.

[30]. New Nigerian (1981) - Publishers New Nigerian Newspapers Ltd. Ahmadu Bello Way Kaduna, August pp15.

[31]. Nwankwo, O. (2005) Human Rights of Women: a compilation of International Human Rights Treaties and Instruments: a Publication of Civil Resourceration Center, Abuja.

[32]. Nyityo, G. (2011) Political Centralization in Nigeria: Nature and Transformation ofTiv Society 1900-1965, Ibadan, Book Builders.

[33]. Obasi. I. N. (1999) Research Methodology in Political Science Enugu: Academic Publishing Company. Pp XIX.

[34]. Obikeze, D.S (1986) Introductory Statistics for the Social Sciences. Enugu: FourthDimension Publishers pp27.

[35]. Odey, M. O. \& Onekutu, P. (2003) the changing Roles of Women in NationalDevelopment: ed in Review of Gender studies in Nigeria Vol. 2

[36]. Olaluwuye, O. (1995) "Feminist Aesthetics in Selected works of Buchi Emecheta"An unpublished M.A. Thesis submitted to the Dept of English, Obafemi Awolowo University.

[37]. Oke, O. (2009). The Developments of Female Autonomy and Influence on fertility in Ibadan: (ed) in Gender and behavior: Vol. 7 No 1

[38]. Okello, O. (1981) Health Problem in Rural and Urban Africa, A Nigerian Political Economy Health Science ed. Zaria, Gaskiya Corporation Ltd.

[39]. Okoche, A O. S. (2008) Discrimination Against Women: A challenge of Nation as development. (ed) The Journal of Family Development, Vol. 3 p 249-256

[40]. Pearce, T.O. (2000). Death and maternity in Nigeria. In: M. Turshen (ed.), African Women's Health, pp. 1-26. Asmara, Eritrea: Africa World Press, Inc.

[41]. Rankin, W., and Wilson, C. (2000). African women with HIV: Faith based answers might ease the social problems that lead to AIDS [Editorial]. British Medical Journal 21(7276): 1543-1544.

[42]. Terry, G. (2007) Women's Rights; London, Pluto press"This is Benue" A Government Publication, Directorate of Information Makurdi.UNICEF (2005). Retrieved February 24, 2005, from http://www.unicef.org/french/nutrition/index_lowbirthweight.html

[43]. 62 Cameroonian Women's Perceptions of their Health Care Needs Wallace, H.M., and Giri, K. (eds.) (1990). Health care of women and children in developing countries. Oakland, California: Third Party Publishing Company.

[44]. Weekes-Vagliani, W. (1985). Women, food and rural development. In: T. Rose (ed.), Crisis and recovery in sub-Saharan Africa, pp. 104-110. Paris: Organization for Economic Cooperation and Development.

[45]. World Health Organization (1996). Maternal mortality figures substantially underestimated. Nation's Health. Cited in: J. Leslie, S.B. Essama, and E. Ciemins 2004, Female nutritional status across the life-span in sub-Saharan Africa. 1. Prevalence patterns. Food and Nutrition Bulletin, 18(1). Retrieved December 9, 2004 from

\section{INTERVIEWS}

1. Dr. Shinyi G.-- Chief Gaena-Cologist, General Hospital Makurdi.

2. Sister Amodu E. (Mrs) Nursing Sister Maternal and Child Care Centre Makurdi.

3. Chief Statistic Officer, Benue State Health Services Management Board Makurdi.

4. Chief Nursing Officer/Gaenacologist, General Hospital Makurdi 